\title{
Determining Mercury in Sediment Samples by Extraction Using a Novel-Chelating Reagent Dithiothreitol (DTT) Followed by Cold Vapor Atomic Fluorescence Spectrometry (CV-AFS)
}

\author{
Robson M. de Jesus, ${ }^{a, b}$ Geovani C. Brandão, ${ }^{c}$ Walter N. L. dos Santos, ${ }^{b, c}$ \\ Leila O.dos Santos ${ }^{b, d}$ and Jailson B. de Andrade ${ }^{\circledR *, a, b, e}$ \\ ${ }^{a}$ Centro Interdisciplinar de Energia e Ambiente (CIEnAm), \\ Universidade Federal da Bahia (UFBA), 40170-115 Salvador-BA, Brazil \\ ${ }^{b}$ Instituto Nacional de Ciência e Tecnologia em Energia e Ambiente (INCT E\&A), \\ Universidade Federal da Bahia (UFBA), 40170-290 Salvador-BA, Brazil \\ ${ }^{c}$ Departamento de Ciências Exatas e da Terra, \\ Universidade do Estado da Bahia (UNEB), 41150-000 Salvador-BA, Brazil \\ ${ }^{d}$ Centro de Formação em Tecno-Ciências e Inovação, \\ Universidade Federal do Sul da Bahia (UFSB), 45613-204 Itabuna-BA, Brazil \\ eSENAI-CIMATEC, Centro Universitário, 41650-010 Salvador-BA, Brazil
}

\begin{abstract}
A new analytical protocol has been developed for the determination of mercury in surface sediments using dithiothreitol (DTT) as a new chelating reagent for the extraction. This protocol requires a small sample mass $(250 \mathrm{mg}), 4.0 \mathrm{~mL}$ of a $0.1 \mathrm{M}(\mathrm{pH}=9.0)$ aqueous DTT solution, and sonication for $30 \mathrm{~min}$, followed by cold vapor atomic fluorescence spectrometry (CV-AFS). The limits of detection and quantification determined were 6 and $18 \mathrm{ng} \mathrm{g}^{-1}$, respectively. The method was validated using three standard reference materials, SRM NIST 1646a, PACS-2, and MESS-3, with recoveries in the range of $102-124 \%$. The new analytical protocol was successfully applied in riverine surface sediments, revealing concentrations in the range of 220-340 $\mathrm{ng} \mathrm{g}^{-1}$. The results obtained by CV-AFS were compared to those obtained by DMA-80 (direct mercury analyzer). The linear regression equation obtained was $[\mathrm{CV}-\mathrm{AFS}]=(0.91 \pm 0.07)[\mathrm{DMA}-80]+(0.04 \pm 0.02)$, revealing no systematic difference between the analytical methods. Hence, the proposed method does not require the complete digestion of the sediment, and was found to be comprehensive, simple, accurate and suitable to be employed for determination of mercury in sediment samples.
\end{abstract}

Keywords: dithiothreitol, mercury, sediments, cold vapor, direct $\mathrm{Hg}$ analyzer

\section{Introduction}

Mercury is an element, non-essential, toxic and bioaccumulative. Mercury is introduced into the environment from natural and anthropogenic sources, and it is a metallic element that is considered to be a global environmental pollutant. ${ }^{1-5}$ In this way, humans and biota are globally exposed to mercury, often at levels that raise health and ecosystem concerns. ${ }^{6,7}$ For these reasons, mercury is considered to be a high-risk pollutant due to its wide distribution, high toxicity, and significant residence times in environmental compartments. ${ }^{8}$ Hence, determining

*e-mail: jailsondeandrade@ gmail.com the concentration and distribution of $\mathrm{Hg}$ in the environment, especially in sediments, is one of the most effective ways of evaluating the degree of environmental $\mathrm{Hg}$ pollution. .-11 $^{-11}$

Most analytical methods employed to determine mercury in sediments and other environmental samples involve the complete decomposition of the matrix through microwave assisted acid extraction, followed by quantification using spectrometric techniques, augmented with a cold vapor generation (CVG) or specific direct mercury analyzer (DMA). ${ }^{12-17}$ In the case of mercury speciation, hyphenated techniques, combining separation and quantification techniques, are used in most cases. ${ }^{18-21}$

Dithiothreitol (DTT), with a redox potential of $-0.33 \mathrm{~V}$ at $\mathrm{pH} 7$, is a reducing agent, in which the $\mathrm{p} K_{\mathrm{a}}$ of a thiol 
group is in the range of 8.3 to 9.0 , generally used in assays for oxidative stress. ${ }^{22-26}$ Nevertheless, despite being a strong chelating molecule, few studies ${ }^{27-31}$ focused on DTT-metal ion interactions have been published. Recent studies $^{30}$ investigated the coordination modes of DTT with divalent metals, such as $\mathrm{Ni}^{2+}, \mathrm{Zn}^{2+}, \mathrm{Cd}^{2+}, \mathrm{Pb}^{2+}$ and $\mathrm{Cu}^{1+}$, and demonstrated that DTT is a very efficient chelating agent. More recently, studies ${ }^{31}$ also showed that $\mathrm{Hg}^{2+}$ ions could bind to the thiol groups of most proteins.

In this study, we propose an analytical methodology that does not require complete sample digestion to determine $\mathrm{Hg}$ in sediments. $\mathrm{Hg}$ is quantitatively extracted from the sediment using a new chelating reagent, DTT. The developed analytical method involves analysis of the supernatant by cold vapor atomic fluorescence spectrometry (CV-AFS) following ultrasonic extraction. The experimental conditions for the extraction process were optimized using multivariate methods. ${ }^{32}$ The developed protocol does not require the complete decomposition of the sample, and provides a simple, accurate, and efficient method for mercury determination in sediment samples. This new analytical procedure may become an important tool for studying the possible origins of mercury present in sediments. To prove the effective applicability of the analytical methodology presented in this work, the mercury concentrations in sediments were also determined employing the analytical technique direct mercury analyzer DMA-80.

\section{Experimental}

\section{Sample collection and site characteristics}

Surface riverine sediment samples were collected using a van Veen dredge at seven points along the Paraguaçu River, located between the municipalities of São Felix and Cachoeira, Bahia, Brazil. The samples were put up in plastic bags previously cleaned, decontaminated, and labelled, and kept in a cool box cooled with ice until they arrived at the laboratory and then stored in a freezer. The samples were stored in glass containers that were decontaminated prior to use and preserved in a thermal box cooled with ice. The samples were dried in the laboratory by lyophilization (Alpha1-4/LD plus, Martin Christ). After drying, the samples were ball milled (SPEX Sample Prep, 8000D Mixer/Mill ${ }^{\circledR}$ ) to increase the surface/volume ratio and ensure that the samples were homogeneous. After milling, the samples were stored in glass containers and stored in a desiccator up until analysis. Additional information about the sampling sites can be found elsewhere. ${ }^{33}$
Reagents, solutions, and standards

All solutions were prepared with analytical grade reagents and ultrapure water, at a resistivity of $18.2 \mathrm{M} \Omega \mathrm{cm}$ (Milli-Q system, Millipore, Bedford, MA, USA). The reagents used, namely dithiothreitol (DTT) (99\%) and trizma hydrochloride (99\%), were obtained from Sigma-Aldrich (Saint Louis, Missouri, USA). The DTT stock solution was prepared to a final concentration of $0.1 \mathrm{M}$ by dissolving $0.154 \mathrm{~g}$ of DTT in $10 \mathrm{~mL}$ ultrapure water. Tris- $\mathrm{HCl}$ buffer solution was prepared to a concentration of $0.4 \mathrm{M}$ and adjusted to $\mathrm{pH}$ 9.0. Standard solutions were prepared by diluting a Hg stock solution (1000 $\mathrm{mg} \mathrm{L}^{-1}$, Specsol, Quimlab, Jacareí, SP, Brazil). Sodium tetrahydroborate solutions, $1.5 \% \mathrm{~m} \mathrm{v}^{-1}$ (Sigma-Aldrich, Saint Louis, Missouri, USA), were prepared daily by dissolving the salt in $0.5 \%\left(\mathrm{~m} \mathrm{v}^{-1}\right)$ sodium hydroxide solution (Merck, Darmstadt, Germany). A 6.0 M hydrochloric acid solution was prepared by diluting $35 \%\left(\mathrm{~m} \mathrm{~m}^{-1}\right)$ hydrochloric acid (Synth, Diadema, SP, Brazil) with ultrapure water. This solution was used to acidify the standard and sample solutions to final $\mathrm{HCl}$ concentrations of $1.0 \mathrm{M}$.

Standard reference materials (SRM) MESS-3 and PACS-2 (National Research Council, Canada) and the standard estuarine sediment reference material SRM NIST 1646a (National Institute of Standards and Technology, USA) were used to evaluate the accuracy of the developed method.

\section{Analytical instrumentation}

Mercury was determined using a vapor generator system coupled to an atomic fluorescence spectrometer (Lumina 3300, Aurora Instruments Limited, Canada) equipped with a high-intensity mercury lamp $(253.6 \mathrm{~nm})$, a peristaltic pump, a dual stage quartz gas-liquid separator (GLS), and a quartz atomizer. Additional information about the equipment is found elsewhere. ${ }^{34,35}$ Argon (99.999\% purity; White Martins, Salvador, BA, Brazil) at a flow rate of $400 \mathrm{~mL} \mathrm{~min}^{-1}$ was used to transport the cold $\mathrm{Hg}$ vapor to the quartz cell, and also to act as a shield (flow rate $=800 \mathrm{~mL} \mathrm{~min}^{-1}$ ). The AFS operating parameters used to determine $\mathrm{Hg}$ were: lamp current $=30 \mathrm{~mA}$, photomultiplier tube $($ PMT) voltage $=350 \mathrm{~V}$, and the flow rate for the introduction of standard solutions and samples was $4.0 \mathrm{~mL} \mathrm{~min}^{-1}$.

Optimization of the ultrasonic extraction procedure for mercury $(\mathrm{Hg})$ in sediments

To investigate the statistical significance of each major 
factor influencing the $\mathrm{Hg}$ extraction process from sediments using DTT as the complexing reagent in conjunction with ultrasonication, we applied a two-level full factorial design. The main effects, as well as all interaction effects, were then determined for the following factors: concentration of DTT (CDTT), sonication time (ST), and $\mathrm{pH}$. In the optimizing experiments were used $25.0 \mathrm{mg}$ of the SRM PACS-2 standard reference material in $10.0 \mathrm{~mL}$ of the extractant and $0.1 \mathrm{M}(\mathrm{pH}=9.0)$ aqueous DTT solution. In order to evaluate the experimental error of the extraction procedure, the central point $(\mathrm{CP})$ was determined in triplicate using CV-AFS. Statistica 10.0 software $^{36}$ was used to process the data.

\section{Procedure of determining $\mathrm{Hg}$ by CV-AFS}

The specific conditions adopted for $\mathrm{Hg}$ cold vapor generation and quantification have been carefully investigated. In this way, acidic standard solutions of the analyte and samples were mixed with a reducing solution $\mathrm{NaBH}_{4}\left(1.5 \%\left(\mathrm{~m} \mathrm{v}^{-1}\right)\right)$ stabilized in $\mathrm{NaOH}\left(1.5 \%\left(\mathrm{~m} \mathrm{v}^{-1}\right)\right)$ to generate the mercury cold vapor. All solutions were propelled by a peristaltic pump coupled to the instrument and transported into the reaction cell at a flow rate of $4.0 \mathrm{~mL} \mathrm{~min}^{-1}$ through corning tubing. In this reaction cell, which was also used as the first gas-liquid separator, the solutions were mixed forming the mercury cold vapor. After gas-liquid separation, the cold mercury vapor was transported to a second gas-liquid separator using argon as the carrier gas at a flow rate of $400 \mathrm{~mL} \mathrm{~min}^{-1}$. Details can be found elsewhere. ${ }^{34,35}$

Procedure for ultrasonically extracting mercury $(\mathrm{Hg})$ in sediments using DTT as the complexing reagent

To extract $\mathrm{Hg}$ from sediment samples, $250 \mathrm{mg}$ sediment samples were directly weighed in conical glass tubes. $2.5 \mathrm{~mL}$ of $0.4 \mathrm{M}$ Tris- $\mathrm{HCl}$ buffer solution and $4.0 \mathrm{~mL}$ of the aqueous 0.1 M DTT solution were added to each tube. Afterwards, ultrapure water was added to a final total volume of $10.0 \mathrm{~mL}$. Each tube was sonicated for $30 \mathrm{~min}$ and centrifuged at $1500 \mathrm{rpm}$ for $3 \mathrm{~min}$. A $5.0 \mathrm{~mL}$ aliquot of the supernatant was transferred for $15 \mathrm{~mL}$ corning tube, then $2.0 \mathrm{~mL}$ of a $6.0 \mathrm{M}$ hydrochloric acid solution were added, and the volume adjusted to $10.0 \mathrm{~mL}$ with ultrapure water. $\mathrm{Hg}$ was quantified by CV-AFS as described in "Procedure determining Hg by CV-AFS" sub-section. The developed method was validated using relevant analytical parameters according to IUPAC recommendations ${ }^{37}$ as described in "Method validation" sub-section.
Instrumentation and analytical procedures for determination of the mercury $(\mathrm{Hg})$ by DMA-80

For comparison, mercury was determined in the sediments using a direct analyzer DMA-80 (Tricell, Milestone, Sorisole, Italy) as well. DMA-80 does not require sample pre-treatment. The sediments samples (100 mg) were accurately weighted in nickel boats, which were inserted in the DMA-80, followed by the steps of sample drying, thermal decomposition, and electrothermal atomization of mercury. Samples were submitted to a heating program: (i) drying $\left(80 \mathrm{~s}\right.$ at $200{ }^{\circ} \mathrm{C}$ ); (ii) thermal decomposition $\left(650{ }^{\circ} \mathrm{C}\right.$ for $\left.180 \mathrm{~s}\right)$; (iii) analytical signal collection and cooling (100 s). A continuous flow of oxygen carries the decomposition products through a hot catalyst bed where gaseous $\mathrm{Hg}$ are trapped. All mercury species are reduced to $\mathrm{Hg}(0)$ and are then carried along with reaction gases to a gold amalgamator where the mercury is selectively trapped. All non-mercury vapors and decomposition products are flushed from the system by the continuous flow of gas. The amalgamator is subsequently heated and releases all trapped mercury to the single beam, fixed wavelength atomic absorption spectrophotometer Mercury, thermally desorbed, was quantified in an optical cell via atomic absorption spectrometry at $253.7 \mathrm{~nm}$. The developed method was validated using relevant analytical parameters according to IUPAC recommendations ${ }^{37}$ as described in "Method validation" sub-section.

\section{Results and Discussion}

\section{Optimization of the $\mathrm{Hg}$ extraction procedure}

A two-level full factorial design was used to investigate the experimental conditions for the extraction of $\mathrm{Hg}$, including, as well, the chelating reagent concentration (CDTT), pH, and ultrasound extraction time (ST), as factors. The design matrix with coded and real values for the investigated factors, and the results acquired for each experiment, are presented in Table 1.

The influence of each factor on the response is evident from the Pareto chart (Figure 1). The chelating reagent concentration (CDTT) and ultrasound extraction time (ST) exhibited significantly positive effects on the response while $\mathrm{pH}$ showed a significant negative effect.

The positive effect of the CDTT on the extraction process is possibly ascribable to free thiolates groups $\left(\mathrm{S}^{-}\right)$ that have high coordination affinities for $\mathrm{Hg}^{2+}$ and form soluble $\mathrm{ML}_{2}$ complexes structures between the divalent tetrahedral metal ions and DTT, as illustrated in Figure 2. ${ }^{30}$ In the same way, sonication time showed a positive effect 
Table 1. Two-level full factorial design matrix applied to evaluate the main factors that influence the ultrasound extraction process of $\mathrm{Hg}$ in sediments

\begin{tabular}{lcccc}
\hline Experiment & $\begin{array}{c}\mathrm{CDTT} / \\
\left(\mathrm{mol} \mathrm{L}^{-1}\right)\end{array}$ & $\mathrm{ST} / \mathrm{min}$ & $\mathrm{pH}$ & Intensity \\
\hline 1 & $0.01(-1)$ & $10(-1)$ & $7.0(-1)$ & 258 \\
2 & $0.04(1)$ & $10(-1)$ & $7.0(-1)$ & 507 \\
3 & $0.01(-1)$ & $50(1)$ & $7.0(-1)$ & 325 \\
4 & $0.04(1)$ & $50(1)$ & $7.0(-1)$ & 438 \\
5 & $0.01(-1)$ & $10(-1)$ & $11.0(1)$ & 169 \\
6 & $0.04(1)$ & $10(-1)$ & $11.0(1)$ & 167 \\
7 & $0.01(-1)$ & $50(1)$ & $11.0(1)$ & 244 \\
8 & $0.04(1)$ & $50(1)$ & $11.0(1)$ & 328 \\
$\mathrm{CP}$ & $0.025(0)$ & $30(0)$ & $9.0(0)$ & 444 \\
$\mathrm{CP}$ & $0.025(0)$ & $30(0)$ & $9.0(0)$ & 413 \\
$\mathrm{CP}$ & $0.025(0)$ & $30(0)$ & $9.0(0)$ & 424 \\
\hline
\end{tabular}

Coded values between parentheses. CDTT: dithiothreitol concentration; ST: sonication time; CP: central point.

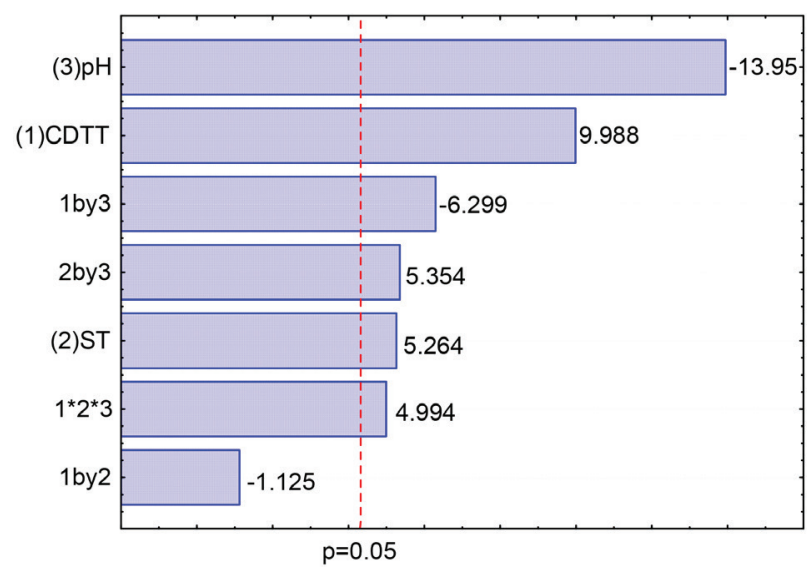

Figure 1. Pareto chart of the two-level full factorial design. (1) Dithiothreitol (DTT) concentration, (2) sonication time (ST), and (3) pH.

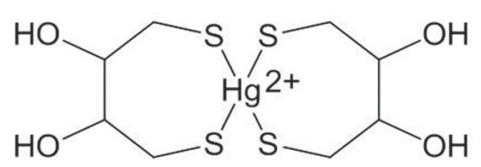

Figure 2. Depicting the $\mathrm{ML}_{2}$ complexes structures of divalent tetrahedral metal ions with DTT (adapted from reference 30 ).

on the ultrasound extraction/reaction process, increasing the extraction efficiency as well as the analytical signal..$^{38-40}$

The $\mathrm{pH}$ had a significant but negative effect, which indicates that higher analytical signals were obtained at $\mathrm{pH}$ above 7 and below pH 11. Hence, it is in agreement with the $\mathrm{p} K_{\mathrm{a}}$ of a thiol group which is typically about 8.3-9.0, providing free thiolates $\left(\mathrm{S}^{-}\right)$groups that coordinate with $\mathrm{Hg}^{2+}$ (Figure 2). Furthermore, except for the CDTT $\times \mathrm{ST}$, interactions between all factors were found to be statistically significant.
The curvature (calculated by the equation 1) is a relevant parameter that can also be used to evaluate the results obtained by factorial design, specially the analytical response around the central point of the experimental domains of the studied factors. ${ }^{32,41}$

Curvature $=\mathrm{R}_{\mathrm{FD}}-\mathrm{R}_{\mathrm{CP}}$

where $\mathrm{R}_{\mathrm{FD}}$ is the average of the responses obtained from the factorial design experiments and $\mathrm{R}_{\mathrm{CP}}$ is the average of the responses obtained from the central point experiments.

According to the curvature test, three results are possible: curvature $>0$, which indicates experimental conditions of minimum response located in the region of the central point of the experimental design; curvature $<0$, which indicates experimental conditions of maximum response in the region of the central point of the experimental design; and curvature $=0$, which indicates that there are no experimental conditions with maximum or minimum responses in the region of the central point. The curvature calculated in this work was -0.0123 , indicating that there are experimental conditions of maximum analytical signal in the central point region for the experimental domains of the studied factors. ${ }^{41}$ In this way, central point experimental conditions were determined for the extraction procedure; however, the DTT concentration was maintained at the maximum level to guarantee a large concentration of deprotonated DTT species, as excess DTT favors the formation of the complex with $\mathrm{Hg}^{2+}$.

According to the results of the two-level full factorial design (Table 1) and analysis of the significance of the effects of the variables and the possible interactions between them, through the Pareto diagram (Figure 1), it was possible to establish the best experimental conditions for the proposed methodology. Hence, the established experimental conditions employed for the mercury extraction in the sediment samples were: DTT concentration $=0.04 \mathrm{~mol} \mathrm{~L}^{-1}$, ultrasound extraction time $=30 \mathrm{~min}$, and $\mathrm{pH}=9.0$.

\section{Method validation}

The developed methods were validated using relevant analytical parameters according to IUPAC recommendations. ${ }^{37}$ The figures of merit of the presented method for mercury determination in sediment samples employing CV-AFS and DMA-80 were performed according to IUPAC..$^{37}$ The limit of detection (LOD) was calculated as three times the standard deviation of ten blank measurements divided by the slope of the calibration curve (sensitivity), and the limit of quantification (LOQ) was determined as ten times the same standard deviation divided 
by the slope of the analytical curve. ${ }^{37}$ Precision is expressed as the relative standard deviation (RSD, in percentage) of eight independent measurements for a surface riverine sediment samples that contained a $\mathrm{Hg}$ concentration of $0.22 \mathrm{mg} \mathrm{kg}^{-1}$. $^{37}$

Method validation was done by relevant analytical figures, such as linear range of the calibration curve (0.5-5.0 $\left.\mu \mathrm{g} \mathrm{L}^{-1}\right)$, the linear regression equation $\left(67.163 \mathrm{C}_{\mathrm{Hg}}+1.083\right)$, coefficient of determination $\left(\mathrm{R}^{2}=0.9950\right)$, limits of detection ( $\left.\mathrm{LOD}=6 \mathrm{ng} \mathrm{g}^{-1}\right)$ and quantification (LOQ $\left.=18 \mathrm{ng} \mathrm{g}^{-1}\right)$, precision $(\mathrm{n}=8$, expressed as RSD $=8.3 \%$ ), and accuracy of the developed method. The accuracy of the method was evaluated by analyzing the SRM NIST 1646a, MESS-3, and PACS-2 standard reference materials, as shown in Table 2.

Table 2. Accuracy for the proposed method for determination of mercury by CV-AFS

\begin{tabular}{lccc}
\hline & $\begin{array}{c}\text { Certificate value / } \\
\left(\mathrm{mg} \mathrm{kg}^{-1}\right)\end{array}$ & $\begin{array}{c}\text { Found value / } \\
\left(\mathrm{mg} \mathrm{kg}^{-1}\right)\end{array}$ & Recovery / \% \\
\hline SRM MESS-3 & $0.091 \pm 0.009$ & $0.112 \pm 0.014$ & 124 \\
SRM PACS-2 & $3.04 \pm 0.20$ & $3.11 \pm 0.36$ & 102 \\
SRM NIST 1646a & $0.040^{\mathrm{a}}$ & $0.046 \pm 0.030$ & 115 \\
\hline
\end{tabular}

${ }^{a}$ Reference value. SRM: standard reference material.

The results obtained for accuracy in this study (Table 2) showed that mercury extraction in different standard reference materials analyzed using dithiothreitol (DTT) as chelating reagent followed quantification by CV-AFS is efficient for mercury determination in sediment samples, presenting good recovery results for the standard reference materials analyzed, exhibiting good confidence in the measurements performed for sediment samples.

The main figures of merit considered in determining mercury using the direct mercury analyzer (DMA-80) were: linear range (cell $0=0.010-3 \mathrm{ng}$; cell $1=3-10 \mathrm{ng}$; cell $2=10-100 \mathrm{ng}$ ); linear regression (cell $0=0.1410 \mathrm{~m}_{\mathrm{Hg}}+$ 0.0004 ; cell $1=0.0510 \mathrm{~m}_{\mathrm{Hg}}+0.0064 ;$ cell $2=0.00085 \mathrm{~m}_{\mathrm{Hg}}+$ 0.00019); determination coefficient $\left(\mathrm{R}^{2}\right)=0.9994,0.9991$, 0.9990 , respectively; $\mathrm{LOD}=0.004 \mathrm{ng}, \mathrm{LOQ}=0.012 \mathrm{ng}$, precision $(n=8$, expressed as RSD $=3.0 \%)$. The accuracy for determination of $\mathrm{Hg}$ by direct mercury analyzer (DMA-80) are shown in Table 3 and are comparable with those shown in Table 2.

\section{Determination of mercury in real samples}

The proposed method was used to determine mercury in surface riverine sediment samples collected at seven different points alongside the Paraguaçu River, Bahia,
Table 3. Accuracy of the method for determination of mercury by DMA- 80

\begin{tabular}{lccc}
\hline & $\begin{array}{c}\text { Certificate value / } \\
\left(\mathrm{mg} \mathrm{kg}^{-1}\right)\end{array}$ & $\begin{array}{c}\text { Found value / } \\
\left(\mathrm{mg} \mathrm{kg}^{-1}\right)\end{array}$ & Recovery / \% \\
\hline SRM MESS-3 & $0.091 \pm 0.009$ & $0.095 \pm 0.001$ & 104 \\
SRM PACS-2 & $3.04 \pm 0.20$ & $3.13 \pm 0.16$ & 103 \\
SRM NIST 1646a & $0.040^{\mathrm{a}}$ & $0.043 \pm 0.006$ & 107 \\
\hline
\end{tabular}

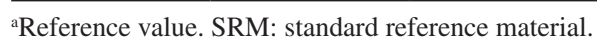

Brazil. The Hg concentrations determined by CV-AFS (Table 4) varied in the range of 0.22 to $0.34 \mathrm{mg} \mathrm{kg}^{-1}$ (average: $0.26 \mathrm{mg} \mathrm{kg}^{-1}$ ). On the other hand, the concentrations obtained by DMA-80, for the same samples (Table 4) varied in the range of 0.24 to $0.35 \mathrm{mg} \mathrm{kg}^{-1}$ (average: $0.28 \mathrm{mg} \mathrm{kg}^{-1}$ ). The results obtained using both analytical methodology presented in this study, CV-AFS and DMA-80 (Table 4), were statistically comparable by applying the following statistical tests: $F$-test to compare the equality of variances in the dataset, followed by Student's $t$-test to assess whether there is no significant difference between the averages of the two data sets. From the $F$-test, we can infer that for a $95 \%$ confidence level, the $F_{\text {calculated }}=1.214$ and the $F_{\text {critical }}=5.050$, thus indicating that the $F_{\text {calculated }}<F_{\text {critical }}$. For the Student's $t$-test, applied at a confidence level of $95 \%, t_{\text {calculated }}=0.802$, and $t_{\text {critical }}=2.228$, therefore $t_{\text {calculated }}<t_{\text {critical }}$. The results of the statistical analysis applied to the data sets showed that there are no significant statistical differences among the data sets. In the same way, the results obtained by CV-AFS were compared with those achieved by DMA- 80 using the linear regression method.

Table 4. Concentrations of mercury found in surface riverine sediment samples collected alongside the Paraguaçu River, Bahia, Brazil

\begin{tabular}{lcc}
\hline \multirow{2}{*}{ Sample } & \multicolumn{2}{c}{$[\mathrm{Hg}] \pm$ standard deviation $/\left(\mathrm{mg} \mathrm{kg}^{-1}\right)$} \\
\cline { 2 - 3 } 1 & CV-AFS & DMA- 80 \\
\hline 2 & $0.24 \pm 0.02$ & $0.26 \pm 0.02$ \\
3 & $0.34 \pm 0.01$ & $0.35 \pm 0.01$ \\
4 & $0.25 \pm 0.02$ & $0.27 \pm 0.02$ \\
5 & $0.22 \pm 0.01$ & $0.24 \pm 0.02$ \\
6 & $0.24 \pm 0.02$ & $0.26 \pm 0.02$ \\
7 & $0.25 \pm 0.02$ & $0.27 \pm 0.02$ \\
Average $\pm \mathrm{IC}^{\mathrm{a}}$ & $0.26 \pm 0.01$ & $0.28 \pm 0.02$ \\
\hline
\end{tabular}

${ }^{\mathrm{a}}$ Confidence interval. CV-AFS: cold vapor atomic fluorescence spectrometry; DMA: direct mercury analyzer.

The equation obtained was the following:

$[\mathrm{CV}-\mathrm{AFS}]=(0.91 \pm 0.07)[\mathrm{DMA}-80]+(0.04 \pm 0.02)(2)$ 
The slope $(0.91 \pm 0.07)$ and intercept $(0.04 \pm 0.02)$, expressed as confidence interval at $95 \%$ level of the linear regression method, demonstrate that there is no evidence of a systematic difference between the two methods (DMA-80 and CV-AFS) employed for mercury determination in the surface riverine sediment samples. Hence, the obtained slope and intercept do not differ significantly from the "ideal" values of 1 and 0 , respectively.

The results obtained in this study were compared with other works published in the literature (Table 5

Table 5. Concentration of $\mathrm{Hg}$ associated to the surface sediment collected in the Paraguaçu river, located in the surroundings of Todos os Santos Bay, BA, Brazil, and comparison with other studies reported in the literature

\begin{tabular}{|c|c|c|c|c|c|c|}
\hline Local & Sample & Analytical technique & LOD & LOQ & {$[\mathrm{Hg}] /\left(\mathrm{mg} \mathrm{kg}^{-1}\right)$} & Reference \\
\hline $\begin{array}{l}\text { Paraguaçu River, Todos os } \\
\text { Santos Bay, BA, Brazil }\end{array}$ & surface sediment & $\begin{array}{l}\text { CV-AFS and } \\
\text { DMA- } 80\end{array}$ & $\begin{array}{l}6 \mathrm{ng} \mathrm{g}^{-1} \\
0.004 \mathrm{ng}\end{array}$ & $\begin{array}{l}18 \mathrm{ng} \mathrm{g}^{-1} \\
0.012 \mathrm{ng}\end{array}$ & $0.24-0.35$ & this study \\
\hline Rhode Island & sediment cores & DMA-80 & $0.004 \mathrm{ng}$ & $0.012 \mathrm{ng}$ & $0.03-0.38$ & 42 \\
\hline Philippines, Southeast Asia & sediment cores & CV-AFS & ni & $\mathrm{ni}$ & $0.03-0.15$ & 43 \\
\hline China & sediment cores & AFS & $0.003 \mu \mathrm{g} \mathrm{g}^{-1}$ & $\mathrm{ni}$ & $0.01-0.25$ & 44 \\
\hline Todos os Santos Bay, BA, Brazil & surface sediment & DMA-80 & $0.004 \mathrm{ng}$ & $0.012 \mathrm{ng}$ & $0.0021-0.065$ & 45 \\
\hline Kaohsiung Harbor, Taiwan & sediment cores & MHS-FAAS & $0.01 \mathrm{mg} \mathrm{kg}^{-1}$ & ni & $0.4-6.4$ & 46 \\
\hline São Paulo, SP, Brazil & sediment cores & DMA-80 & $0.004 \mathrm{ng}$ & $0.012 \mathrm{ng}$ & $0.14-17.3$ & 47 \\
\hline Himalaya, Tibet & sediment cores & $\begin{array}{l}\text { Leeman Hydra-IIC } \\
\text { Direct Hg Analyzer }\end{array}$ & $<0.01 \mathrm{ng} \mathrm{g}^{-1}$ & ni & $0.006-0.647$ & 48 \\
\hline Southern Italy & sediments & DMA- 80 & $0.004 \mathrm{ng}$ & $0.012 \mathrm{ng}$ & $4.13-22.2$ & 49 \\
\hline $\begin{array}{l}\text { Paraguaçu Estuary, Todos os } \\
\text { Santos Bay, BA, Brazil }\end{array}$ & surface sediment & CV AAS & ni & $\mathrm{ni}$ & $0.05-0.25$ & 50 \\
\hline USA & sediment cores & DMA-80 & ni & $1 \mathrm{ng} \mathrm{g}^{-1}$ & $0.033-0.24$ & 51 \\
\hline China & sediments & $\begin{array}{l}\text { XRF } \\
\text { ICP-MS }\end{array}$ & ni & ni & 0.01-0.09 & 52 \\
\hline China & sediment cores & - & ni & ni & $0.156-0.3$ & 53 \\
\hline Kagoshima Bay, Japan & sediments & CV AAS & ni & ni & $0.05-1.2$ & 54 \\
\hline Thames Estuary London, UK & sediment cores & $\begin{array}{l}\text { advanced mercury } \\
\text { analyser and AAS }\end{array}$ & ni & $0.02 \mathrm{mg} \mathrm{kg}^{-1}$ & $0.01-12.07$ & 55 \\
\hline Shandong, East China & surface sediment & AFS & ni & $\mathrm{ni}$ & $0.032-0.068$ & 56 \\
\hline Peninsular Malaysia, Malaysia & $\begin{array}{c}\text { estuaries and coastal } \\
\text { sediments }\end{array}$ & FIMS 400 & $0.01 \mu \mathrm{g} \mathrm{kg}^{-1}$ & $0.03 \mu \mathrm{g} \mathrm{kg}^{-1}$ & $0.0165-0.114$ & 57 \\
\hline China & sediment cores & CV AAS & ni & ni & $0.007-0.398$ & 58 \\
\hline Minamata and Fukuro Bay, Japan & sediment cores & CV AAS & $\mathrm{ni}$ & ni & $2.47-4.66$ & 59 \\
\hline Bohai Bay, Northern China & surface sediments & CV-AFS & $0.012 \mu \mathrm{g} \mathrm{L}^{-1}$ & ni & $0.099-0.865$ & 60 \\
\hline Southeast Coast of India & estuarine sediments & ICP AES & $0.01 \mathrm{ppm}$ & ni & $0.116-0.776$ & 61 \\
\hline Coast of Southern China & surface sediments & $\begin{array}{l}\text { flow injection } \\
\text { mercury system }\end{array}$ & ni & ni & $0.025-0.264$ & 62 \\
\hline Southern China & sediment cores & CV-AFS & ni & $0.5 \mathrm{ng} \mathrm{g}^{-1}$ & $0.109-0.453$ & 10 \\
\hline Guanabara Bay, RJ, Brazil & sediment cores & CV-AFS & $0.1 \mathrm{ng} \mathrm{L}^{-1}$ & ni & $0.1-3.22$ & 63 \\
\hline Augusta Bay, Italy & sediments & AAS, ICP AES & ni & ni & $0.25-575$ & 64 \\
\hline German & sediments & EDXR & ni & $\mathrm{ni}$ & $1.0-149$ & 65 \\
\hline China & sediment cores & AFS & ni & $0.002 \mathrm{mg} \mathrm{kg}^{-1}$ & $0.05-0.3$ & 66 \\
\hline $\begin{array}{l}\text { Southwestern French Mediterranean } \\
\text { Coast, France }\end{array}$ & sediment cores & $\begin{array}{l}\text { automatic mercury } \\
\text { analyzer }\end{array}$ & ni & ni & $0.082-0.58$ & 67 \\
\hline South China & surface sediments & $\begin{array}{l}\text { flow injection } \\
\text { mercury system }\end{array}$ & ni & ni & $0.0015-0.201$ & 68 \\
\hline Hudson Bay, Canada & sediment cores & $\begin{array}{c}\text { CV-AFS and mercury } \\
\text { analyzer }\end{array}$ & ni & ni & $0.008-0.058$ & 69 \\
\hline United Kingdom & sediment cores & CV AAS & ni & ni & $0.05-50$ & 70 \\
\hline NW England, UK & sediments & AFS & ni & ni & $0.84-5.13$ & 71 \\
\hline Guanabara Bay, RJ, Brazil & sediment cores & CV AAS & ni & $\mathrm{ni}$ & $0.042-7.5$ & 72 \\
\hline Kaohsiung Harbor, Taiwan & superficial sediments & MHS-10 & ni & ni & $0.01-8.51$ & 73 \\
\hline
\end{tabular}

LOD: limit of detection; LOQ: limit of quantification; CV-AFS: cold vapor atomic fluorescence spectrometry; DMA: direct mercury analyzer; ni: not informed; MHS-FAAS: mercury hydride system-flame atomic absorption spectrometry; CV AAS: cold vapor atomic absorption spectrometry; XRF: X-ray fluorescence spectrscopy; ICP-MS: inductively coupled plasma mass spectrometry; FIMS: flow injection mercury system; ICP AES: inductively coupled plasma atomic emission spectrometry; EDXR: energy dispersive X-ray reflectivity. 
and references cited therein). The method is relatively inexpensive and could be considered as a green analytical method because it requires a small sample amount, low consumption of reagents, and low residue generation. On the other hand, the atomic fluorescence spectrometer is an equipment found in several academic laboratories, which would facilitate the study of mercury in the environment in many places over the world.

The proposed method does not require the complete decomposition of the sample, and was found to be comprehensive, simple, accurate and suitable to be employed for determination of mercury in sediment samples.

\section{Conclusions}

We developed a new analytical protocol for determining mercury in surface sediments using dithiothreitol (DTT) as a new chelating reagent, followed by CV-AFS. We proposed an analytical methodology that does not require complete sample dissolution to determine $\mathrm{Hg}$ in sediments. The analytical method was validated using certified estuarine sediment reference materials and was used to determine mercury in sediment samples. The developed method showed good accuracy, LOD, and LOQ, as well as satisfactory recoveries. The analytical methodology does not require the complete decomposition of the sample, and was found to be comprehensive, simple, accurate and suitable to be employed for determination of mercury in sediment samples.

\section{Acknowledgments}

The authors thank the Brazilian funding agencies, Brazilian National Counsel of Technological and Scientific Development (CNPq, INCT 465497/2014-4), grant No. 442187/2018-1 (Pesquisando Kirimurê: Convergindo Educação, Ciência, Tecnologia e Inovação) and the Coordination for the Improvement of Higher Education Personnel, Brazil (CAPES), finance code 001. National Institute of Science and Technology (INCT), Interdisciplinary Center on Energy and Environment (CIEnAm).

\section{References}

1. World Health Organization (WHO); Exposure to Mercury: A Major Public Health Concern; WHO Public Health and Environment Sector, WHO: Geneva, 2007.

2. Gonzalez-Raymat, H.; Liu, G.; Liriano, C.; Li, Y.; Yin, Y.; Shi, J.; Jiang, G.; Cai, Y.; Environ. Pollut. 2017, 229, 69.
3. Driscoll, C. T.; Mason, R. P.; Chan, H. M.; Jacob, D. J.; Pirrone, N.; Environ. Sci. Technol. 2013, 47, 4967.

4. Pacyna, E. G.; Pacyna, J. M.; Water, Air, Soil Pollut. 2002, 137, 149.

5. Pacyna, E. G.; Pacyna, J. M.; Steenhuisen, F.; Wilson, S.; Atmos. Environ. 2006, 40, 4048.

6. Mahbub, K. R.; Krishnan, K.; Naidu, R.; Andrews, S.; Megharaj, M.; Ecol. Indic. 2017, 74, 451.

7. Jiang, G. B.; Shi, J. B.; Feng, X. B.; Environ. Sci. Technol. 2006, 40, 3672 .

8. United States Environmental Protection Agency (US EPA); EPA-452/R-97-006 An Assessment of Exposure to Mercury in the United States; Office of Air Quality Planning \& Standards and Office of Research and Development: Washington, DC, 1997.

9. Pan, K.; Lee, O. O.; Qian, P. Y.; Wang, W. X.; Mar. Pollut. Bull. 2011, 62, 1140.

10. Yu, X.; Li, H.; Pan, K.; Yan, Y.; Wang, W-X.; Mar. Pollut. Bull. 2012, 64, 1699.

11. Hatje, V.; Andrade, R. L. B.; Jesus, R. M.; Masqué, P.; Albergaria-Barbosa, A. C. R.; de Andrade, J. B.; Santos, A. C. S. S.; Mar. Pollut. Bull. 2019, 145, 396.

12. Butler, O. T.; Cairns, W. R. L.; Cook, J. M.; Mertz-Kraus, R.; Tyson, J. F.; J. Anal. At. Spectrom. 2016, 31, 35.

13. Butler, O. T.; Cairns, W. R. L.; Cook, J. M.; Davidson, C. M.; J. Anal. At. Spectrom. 2012, 27, 187.

14. Dedina, J.; Tsalev, D. L.; Hydride Generation Atomic Absorption Spectrometry; John Wiley: Chichester, UK, 1995.

15. Morita, H.; Tanaka, H.; Shimomura, S.; Spectrochim. Acta, Part B 1995, 50, 69.

16. Sánchez-Rodas, D.; Corns, W. T.; Chen, B.; Stockwell, P. B.; J. Anal. At. Spectrom. 2010, 25, 933.

17. Yan, X. P.; Ni, Z. M.; Anal. Chim. Acta 1994, 291, 89.

18. Chen, J.; Chakravarty, P.; Davidson, G. R.; Wren, D. G.; Locke, M. A.; Zhou, Y.; Brown, G.; Cizdziel, J. V.; Anal. Chim. Acta 2015, 871, 9 .

19. Rezende, P. S.; Silva, N. C.; Moura, W. D.; Windmöller, C. C.; Microchem. J. 2018, 140, 199.

20. Reis, A. T.; Coelho, J. P.; Rodrigues, S. M.; Rocha, R.; Davidson, C. M.; Duarte, A. C.; Pereira, E.; Talanta 2012, 99, 363.

21. Rumayor, M.; Diaz-Somoano, M.; Talanta 2013, 114, 318.

22. Cho, A. K.; Sioutas, C.; Miguel, A. H.; Kumagai, Y.; Schmitz, D. A.; Singh, M.; Eiguren-Fernandez, A.; Froines, J. R.; Environ. Res. 2005, 99, 40.

23. Charrier, J. G.; Anastasio, C.; Atmos. Environ. 2011, 45, 7555.

24. Charrier, J. G.; Anastasio, C.; Atmos. Chem. Phys. 2012, 12, 9321.

25. Charrier, J. G.; Anastasio, C.; Environ. Sci. Technol. 2015, 49, 9317.

26. de Jesus, R. M.; Mosca, A. C.; Guarieiro, A. L. N.; da Rocha, G. O.; de Andrade, J. B.; J. Braz. Chem. Soc. 2018, 29, 1268. 
27. Cornell, W.; Crivaro, K. E.; Anal. Biochem. 1972, 47, 203.

28. Gagliardi, E.; Durst, A.; Monatsh. Chem. 1971, 102, 308.

29. Gnonlonfoun, N.; Filella, M.; Berthon, G.; J. Inorg. Biochem. 1991, 42, 207.

30. Krężel, A.; Leniak, W.; Jeowska-Bojczuk, M.; Mlynarz, P.; Brasu, J.; Kozlowski, H.; Bal, W.; J. Inorg. Biochem. 2001, 84, 77.

31. Clarkson, T. W.; Environ. Health Perspect. 2002, 110, 11.

32. Bruns, R. E.; Scarminio, I. S.; Neto, B. B.; Statistical DesignChemometrics, vol. 25, $1^{\text {st }}$ ed.; Elsevier: Amsterdam, NL, 2006.

33. Santos, L. O.; Santos, A. G.; de Andrade, J. B.; Mar. Pollut. Bull. 2018, 136, 248.

34. da Silva, D. L. F.; da Costa, M. A. P.; Silva, L. O. B.; dos Santos, W. N. L.; Food Chem. 2018, 273, 24.

35. dos Santos, W. N. L.; Cavalcante, D. D.; Gomes, P. D. N.; Santos, D. C. M. B.; Silva, L. O. B.; Curr. Anal. Chem. 2016, $12,102$.

36. StatSoft; Statistica 10.0; StatSoft Inc., Tulsa, OK, USA, 2014.

37. Thompson, M.; Ellison, S. L. R.; Wood, R.; Pure Appl. Chem. 2002, 74, 835 .

38. Collasiol, A.; Pozebon, D.; Maia, S. M.; Anal. Chim. Acta 2004, $518,157$.

39. Leão, D. J.; Silva Jr., M. M.; Silva Jr., J. B.; Queiroz, A. F. S.; Ferreira, S. L. C.; Anal. Methods 2016, 8, 6554.

40. García-Casillas, D.; García-Salgado, S.; Quijano, M. Á.; Anal. Methods 2014, 6, 8403.

41. Massart, D. L.; Vandeginste, B. G. M.; Buydens, L. M. C.; de Jong, S.; Lewi, P. J.; Smeyers-Verbeke, J.; Handbook of Chemometrics and Qualimetrics: Part A, vol. 20, $1^{\text {st }}$ ed.; Elsevier: Amsterdam, NL, 1997.

42. Fitzgerald, W. F.; Engstrom, D. R.; Hammerschmidt, C. R.; Lamborg, C. H.; Balcom, P. H.; Lima-Braun, A. L.; Bothner, M. H.; Reddy, C. M.; Environ. Sci. Technol. 2018, 52, 7614.

43. Engels, S.; Fong, L. S. R. Z.; Chen, Q.; Leng, M. J.; McGowan, S.; Idris, M.; Rose, N. L.; Ruslan, M. S.; Taylor, D.; Yang, H.; Environ. Pollut. 2018, 235, 907.

44. Zhao, G.; Ye, S.; Yuan, H.; Ding, X.; Wang, J.; Environ. Sci. Pollut. Res. 2017, 24, 2966.

45. Fostier, A. H.; Costa, F. N.; Korn, M. G. A.; Environ. Sci. Pollut. Res. 2016, 23, 19686.

46. Chen, C. F.; Ju, Y. R.; Chen, C. W.; Dong, C. D.; Chemosphere 2016, 165, 67.

47. Franklin, R. L.; Fávaro, D. I. T.; Damatto, S. R.; J. Radioanal. Nucl. Chem. 2016, 307, 99.

48. Kang, S.; Huang, J.; Wang, F.; Zhang, Q.; Zhang, Y.; Li, C.; Wang, L.; Chen, P.; Sharma, C. M.; Li, Q.; Sillanpa, M.; Environ. Sci. Technol. 2016, 50, 2859.

49. Oliveri, E.; Salvagio, D.; Bonsignore, M.; Cappello, S.; Tranchida, G.; Bagnato, E.; Sabatino, N.; Santisi, S.; Sprovieri, M.; Mar. Chem. 2016, 186, 1.
50. Pereira, T. S.; Moreira, Í. T. A.; de Oliveira, O. M. C.; Rios, M. C.; Filho, W. A. C. S.; de Almeida, M.; de Carvalho, G. C.; Mar. Pollut. Bull. 2015, 99, 166.

51. Gray, J. E.; Van Metre, P. C.; Pribil, M. J.; Horowitz, A. J.; Chem. Geol. 2015, 395, 80.

52. Hu, G.; Bi, S.; Xu, G.; Zhang, Y.; Mei, X.; Li, A.; Mar. Pollut. Bull. 2015, 96, 434.

53. Li, Q.; Jiang, L.; Wang, D.; Luo, X.; Environ. Contam. Toxicol. 2015, 95, 51 .

54. Ruiz, W. L. G.; Tomiyasu, T.; Environ. Earth Sci. 2015, 1175.

55. Vane, C. H.; Beriro, D. J.; Turner, G. H.; Earth Environ. Sci. Trans. R. Soc. Edinburgh 2015, 285.

56. Wang, Y.; Yang, L.; Kong, L.; Liu, E.; Wang, L.; Zhu, J.; Catena 2015, 125, 200.

57. Looi, L. J.; Aris, A. Z.; Environ. Monit. Assess. 2015, 187, 4099.

58. Meng, M.; Shi, J.; Yun, Z.; Zhao, Z.; Li, H.; Gu, Y.; Shao, J.; Chen, B.; Li, X.; Jiang, G.; Mar. Pollut. Bull. 2014, 88, 347.

59. Tomiyasu, T.; Takenaka, S.; Noguchi, Y.; Kodamatani, H.; Matsuyama, A.; Mar. Chem. 2014, 159, 19.

60. Wu, G.; Shang, J.; Pan, L.; Wang, Z.; Mar. Pollut. Bull. 2014, $82,194$.

61. Magesh, N. S.; Chandrasekar, N.; Kumar, S. K.; Glory, M.; Mar. Pollut. Bull. 2013, 73, 355.

62. Xu, W.; Yan, W.; Huang, W.; Chen, Z.; Wang, S.; Miao, L.; Zhong, L.; Chen, H.; Mar. Pollut. Bull. 2013, 76, 394.

63. Covelli, S.; Protopsalti, I.; Acquavita, A.; Sperle, M.; Bonardi, M.; Emili, A.; Cont. Shelf Res. 2012, 35, 29.

64. Bellucci, L. G.; Giuliani, S.; Romano, S.; Albertazzi, S.; Mugnai, C.; Environ. Sci. Technol. 2012, 46, 2040.

65. Baborowski, M.; Büttner, O.; Morgenstern, P.; Jancke, T.; Westrich, B.; Environ. Pollut. 2012, 167, 115.

66. Yuan, G.; Liu, C.; Chen, L.; Yang, Z.; J. Hazard. Mater. 2011, $185,336$.

67. Elbaz-Poulichet, F.; Dezileau, L.; Freydier, R.; Cossa, D.; Sabatier, P.; Environ. Sci. Technol. 2011, 45, 8642.

68. Shi, J.; Ip, C. C. M.; Zhang, G.; Jiang, G.; Li, X.; Environ. Pollut. 2010, 158, 1974.

69. Hare, A.; Stern, G.; Kuzyk, Z.; Macdonald, R.; Johannessen, S.; Wang, F.; Environ. Sci. Technol. 2010, 44, 5805.

70. Yang, H.; Environ. Pollut. 2010, 158, 2504.

71. Vane, C. H.; Jones, D. G.; Lister, T. R.; Mar. Pollut. Bull. 2009, $58,940$.

72. Machado, W.; Santelli, R. E.; Loureiro, D. D.; Oliveira, E. P.; Borges, A. C.; Ma, V. K.; Lacerda, L. D.; J. Braz. Chem. Soc. 2008, 19, 569.

73. Chen, C.; Kao, C.; Chen, C.; Dong, C.; Chemosphere 2007, 66, 1431.

Submitted: April 7, 2020

Published online: July 1, 2020 